Дорошкевич Н. В., кандидат сільськогосподарських наук Донецький національний університет

\title{
ВИКОРИСТАННЯ ЕЛЕКТРОФОРЕЗУ ДЛЯ ДОДАТКОВОЇ ОЦНКИ НОВИХ IЗОЛЯТІВ ГРИБА PLEUROTUS OSTREATUS (JACQ.: FR.) KUMMER
}

\section{Рецензент - кандидат біологічних наук М. В. Борисюк}

У роботі проведено додаткову оцінку нових ізолятів гриба P. ostreatus за допомогою електрофорезу. Виявлено, шуо здатність гриба продукувати в КР позаклітинні білки з різною відносною електрофоретичною рухливістю є відповідною реакцією на вуглецьвмісні речовини живильного середовища. Встановлено зв'язок між кількістю білкових зон на ЕФС ліофілятів КР після культивування на сусловому середовищі та здатністю гриба накопичувати біомасу за поверхневого культивування на рідкому суслі і його урожайністю на лушпинні соняшника, який можна використовувати для додаткової характеристики нових ізолятів гриба P. ostreatus.

Ключові слова: електрофорез, біомаса, урожайність плодових тіл, продуктивність, ізоляти, ліофіляти, позаклітинні білки.

Постановка проблеми. Плодові тіла їстівних грибів містять значну кількість білка (до 30-40\% сухої маси), незамінних амінокислот, вуглеводів, ліпідів, вітамінів й інших органічних сполук й мають високі органолептичні властивості $[12,14,18]$. Саме тому їстівні гриби $\epsilon$ цінним та екологічно чистим продуктом харчування, що останнім часом усе більш широко використовуються для штучного культивування. Для культивування їстівних грибів використовуються різні рослинні субстрати, зокрема, відходи сільського господарства, що також частково сприяє вирішенню проблеми утилізації відходів $[15,16,18]$.

Найбільш дослідженим об'єктом промислового грибівництва є гриб Pleurotus ostreatus (Jacq.: Fr.) Kummer, який завдяки своїм високим показникам життєздатності, пристосованості до різних субстратів та простого способу інтенсивного культивування займає третє місце в світовому виробництві грибів $[10,18]$.

Аналіз останніх досліджень і публікацій, у яких започатковано розв'язання проблеми. Останнім часом ведеться активний пошук нових культур гриба $P$. ostreatus, які забезпечать отримання високих урожаїв із мінімальними витратами $[4,13]$. В якості джерела нових високопро- дуктивних культур перевага надається природним ізолятам гриба $[4,11,13]$. Автори [17] для добору нових ізолятів гливи звичайної до промислового грибівництва використовують морфологію мицеліальних гіф штамів, фенотип яких стійкий до речовини 2-деоксі-D-глюкози. Іншими авторами [11] доведена можливість застосування належності монокаріонів до тієї чи іншої інтерстерильної групи для характеристики їх важливих господарських ознак.

Однак усі існуючі нині методики визначення морфобіологічних характеристик гриба P. ostreatus тривалі у часі й не дають повної та об'єктивної інформації про доцільність застосування нової культури в грибівництві. Враховуючи вищенаведене, актуальною $є$ розробка нових підходів із використанням класичних методів дослідження для всебічної господарськобіологічної оцінки гриба, за допомогою якої можна зменшити термін визначення перс пективних ізолятів від стадії пошуку до впровадження їх у промислове грибівництво.

Мета досліджень: використання класичного електрофоретичного методу дослідження позаклітинних білків культуральної рідини для додаткової оцінки продуктивності нових ізолятів гриба $P$. ostreatus.

Для досягнення мети були поставлені такі завдання:

- оцінка нових ізолятів гливи звичайної за умов поверхневого культивування на рідкому живильному середовищі $з$ різним джерелом вуглецю;

- інтенсивне культивування нових ізолятів гриба P. ostreatus на твердому вуглецевому субстраті - лушпинні соняшника;

- електрофоретичні дослідження позаклітинних білків культуральної рідини гриба $P$. ostreatus для визначення найперспективніших за біохімічними показниками;

- порівняння даних, отриманих за умов поверхневого, інтенсивного культивування 3 результатами електрофоретичного дослідження. 
Матеріали та методи досліджень. Для роботи взято нові ізоляти гриба P. ostreatus К-99, Р-01, В-99, ВК-2000, Р-15, С-2000, 420, виділених у чисту культуру з плодових тіл згідно з методикою [5]. В якості контролю використано штам НК-35, який культивується у промисловому грибівництві.

На попередньому етапі для визначення здатності гриба накопичувати біомасу поверхневого міцелію та для отримання культуральної рідини (КР), насиченої позаклітинними білками, досліджені ізоляти культивували на рідкому живильному середовищі з різним вмістом вуглеводів: середовище Чапека 3 глюкозою (30 г/л) і сахарозою (30 г/л), картопляно-сахарозне (сахароза, 30 г/л) і суслове, яке готувалося за методикою С. М. Семенова [8]. Досліди на рідкому середовищі проводили в умовах поверхневої культури в колбах Ерленмейєра ємністю 250 мл, в які наливали 50 мл живильного середовища з подальшою їх стерилізацією в автоклаві 3 температурою $121^{\circ} \mathrm{C}$ під тиском 1 атм протягом години.

Інокуляцію ізолятами колб із приготовленим середовищем проводили шматочками міцелію, попередньо вирощеного на стандартному суслоагаровому середовищі ( $4^{\circ}$ за Баллингом $)$ в пробірках (20x2 см) протягом семи діб. Термін культивування становив 30 діб у термостаті 3 температурою $26^{\circ} \mathrm{C}$ згідно роботи [2]. Здатність гриба накопичувати біомасу оцінювали ваговим методом [5]. Культуральну рідину (КР), насичену позаклітинними білками, фільтрували i ліофільно висушували на приладі «Іній 3-2» за методикою, наведеною в роботі [3].

Електрофоретичний розподіл водорозчинних білків отриманих ліофілятів КР проводили в паралельних пластинках поліакриламідного гелю (ПААГ) за допомогою приладу конструкції К. Л. Трувеллер [9] за методом В. І. Сафонова і М. П. Сафонової [7].

Для внесення проб на гель ліофіляти КР наважкою 0,1 г розводили в співвідношенні 1:1 із $40 \%$ сахарозою $(0,2$ мл) із додаванням однієї краплі барвника - бром-фенолового синього. Пофарбований екстракт вносили по 0,1 мл мікропіпеткою в комірки верхнього гелю. В якості електродного буферу використовували трисгліциновий буфер $(\mathrm{pH}=8,3)$. Час електрофорезу становив 45-90 хв за сили току 4 мА на трубку.

Для прояву електрофореграм на білок гель спочатку фіксували $7 \%$ розчином трихлоруксусної кислоти впродовж 20 хвилин. Потім гель вимивали дистильованою водою $(30$ хв) i фарбували протягом однієї години в 0,2\% розчині барвника Кумассі яскраво-блакитного Г 250. Отримані електрофореграми поміщали в целофан і висушували в сушильній шафі з температурою $70{ }^{\circ} \mathrm{C}$. Білкові компоненти на електрофоретичних спектрах (ЕФС) характеризували на підставі їх відносної електрофоретичної рухливості (ВЕР), що розраховували за формулою В. І. Сафонова і М. П. Сафонової [7]: ВЕР = $\mathrm{R} / \mathrm{R}_{1}$, де $\mathrm{R}$ - відстань від старту до середини зони білка, мм; $\mathrm{R}_{1}$ - відстань від старту до фінішу барвника, мм.

Інтенсивне культивування гриба $P$. ostreatus проведено за стандартною методикою, яку наведено в роботі [1]. Урожайність розраховували через відношення маси свіжих плодових тіл до маси вологого субстрату (г/кг).

Статистичну обробку даних проводили за допомогою дисперсійного аналізу і множинного порівняння середніх за Данетом [6].

Результати досліджень. Встановлено, що здатність гриба P. ostreatus накопичувати біомасу визначається вуглецем живильного середовища та морфобіологічними особливостями ізолятів (рис. 1). Найбільшу здатність накопичувати поверхнево біомасу на середовищі Чапека 3 глюкозою мали ізоляти В-99 і К-99, що в 1,3-1,4 рази перевищувало значення контрольного штаму НК-35. На середовищі Чапека 3 сахарозою найбільшу здатність накопичувати біомасу також виявлено у ізолятів В-99 і К-99, що було на $10 \%$ більше порівняно зі штамом НК-35. На картопляно-сахарозному середовищі найбільшу здатність накопичувати біомасу мали ізолят В-99 i штам НК-35, 8,24 і 7,94 г/л відповідно. За культивування досліджених ізолятів на сусловому середовищі найбільшу здатність накопичувати біомасу мали ізоляти В-99 і К-99 та штам НК-35 (11,58-12,85 г/л).

Таким чином, за результатами поверхневого культивування на рідкому середовищі було визначено два перспективних ізоляти В-99 і К-99, які за показником накопичення біомаси поверхневого міцелію не поступалися контрольному штаму НК-35. Дані інтенсивного культивування свідчать, що за показником, який характеризує урожайність плодових тіл, для ізолятів В-99 і К-99 були вище, ніж в інших ізолятів та у контрольного штаму НК-35 (рис. 2). Видно, що порівняно зі штамом НК-35 урожайність у ізолятів В-99 і К-99 була в $1,8-1,4$ рази вище i становила 262,7 і 216,3 г/кг, відповідно. Ізоляти ВК-2000, P-01 і Р-15 за цим показником незначною мірою відрізнялися від контрольного штаму НК-35 (146,3-160,0 г/кг). 


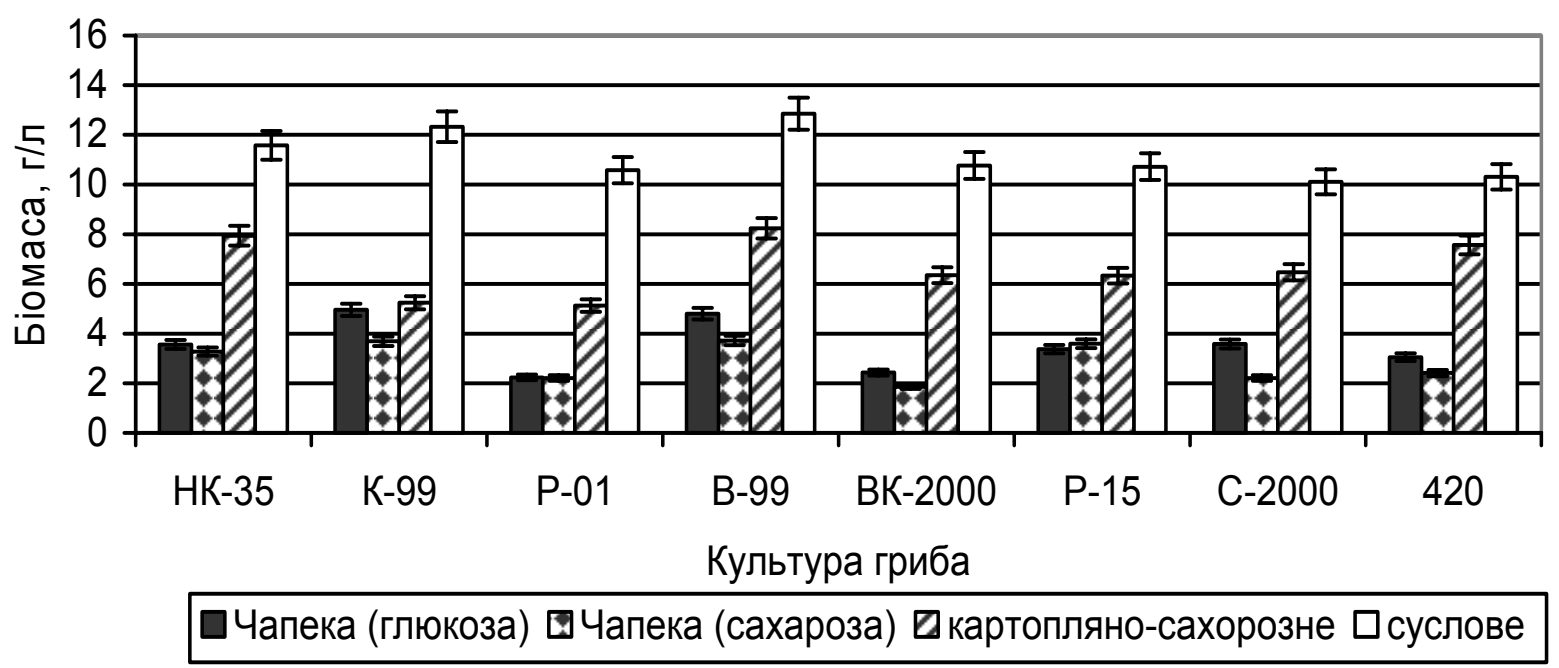

Рис. 1. Діаграмма накопичення біомаси ізолятами гриба P. ostreatus залежно від живильного середовища

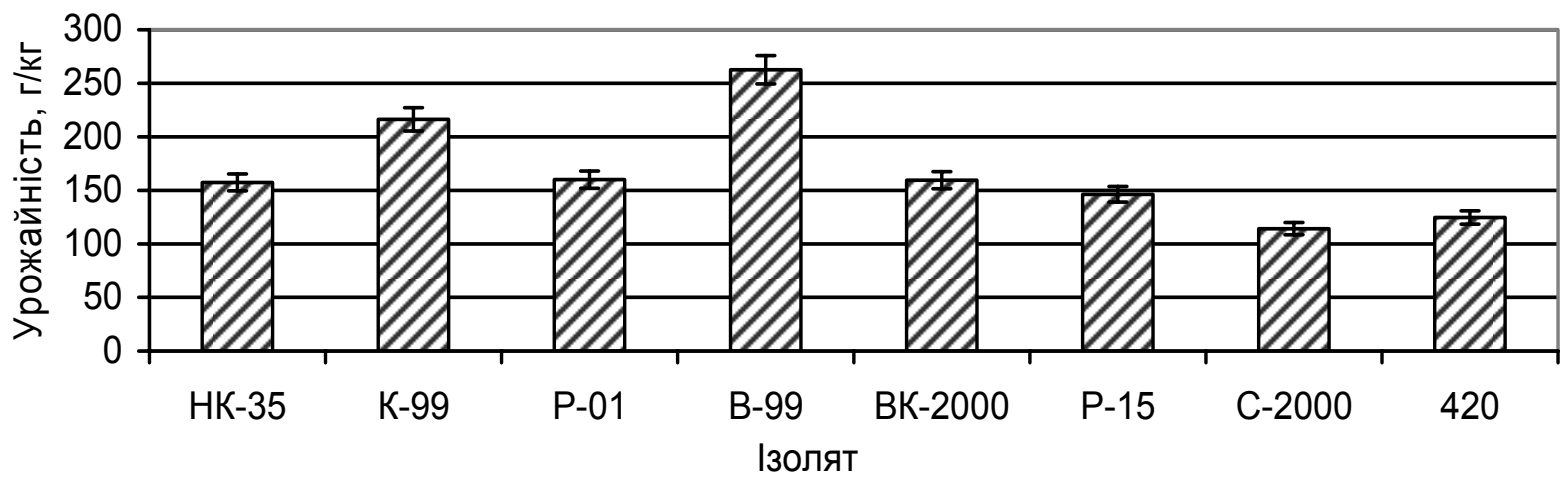

Рис. 2. Діаграма показника урожайності плодових тіл ізолятів гриба Р. оstreatus за інтенсивного культивування на лушпинні соняшника

Таким чином, за результатами інтенсивного культивування на лушпинні соняшника було доведено, що два ізоляти В-99 і К-99, які мали найбільший показник накопичення біомаси на рідкому живильному середовищі (рис. 1), також характеризувалися високою урожайністю плодових тіл.

За результатами електрофоретичних досліджень було показано, що якісний і кількісний склад позаклітинних білків КР залежить від вуглецю живильного середовища та біологічних особливостей кожного дослідженного ізоляту гриба P. ostreatus (табл. 1-2).

3 електрофореграм ліофілятів КР після культивування на середовищі Чапека (глюкоза) видно, що всі ізоляти і штам НК-35 мали однакову реакцію на джерело вуглецевого живлення i продукували тільки один білковий компонент зі швидкою ВЕР, яка дорівнювала 0,70-0,68 (табл. 1).
Із даних табл. 1 видно, що всі ізоляти продукували три основні фракції позаклітинних білків із малорухливою ВЕР, яка дорівнювала 0,09 , 0,15 і 0,21 після їх культивування на картопляносахарозному живильному середовищі. Показано, що ізоляти ВК-2000 і С-2000 мали ще додаткову білкову зону з ВЕР - 0,06.

Аналіз ЕФС ізолятів гриба $P$. ostreatus після культивування на сусловому живильному середовищі показав наявність у КР малорухливих, середньорухливих та швидкорухливих позаклітинних білків (табл. 2).

У контрольного штаму НК-35 виявлено чотири білкові зони, що мали переважно середню ВЕР, яка дорівнювала 0,40, 0,49, 0,60 і 0,66.

У ізолятів К-99 і Р-01 було виявлено п'ять білкових зон, 3 яких чотири мали загальну зі штамом НК-35 середню рухливість $(0,40,0,49,0,60$ і 0,66$)$ i одну білкову зону з малою ВЕР, яка дорівнювала 0,19 . 
СІЛЬСЬКЕ ГОСПОДАРСТВО. РОСЛИННИЦТВО

\section{1. Кількість білкових зон та ВЕР позаклітинних білків гриба Р. ostreatus за вирощування на середовищі Чапека і картопляно-сахарозному середовищі}

\begin{tabular}{|c|c|c|c|c|c|c|c|c|}
\hline \multirow{2}{*}{$\begin{array}{c}\text { Штам, } \\
\text { ізоляти }\end{array}$} & \multicolumn{3}{|c|}{$\begin{array}{c}\text { Середовище Чапека } \\
\text { (глюкоза, 30 г/л) }\end{array}$} & \multicolumn{5}{c|}{$\begin{array}{c}\text { Картопляно-сахарозне середовище } \\
\text { (сахароза, 30 г/л) }\end{array}$} \\
\cline { 2 - 9 } & \multicolumn{2}{|c|}{ номер білкової зони } & \multicolumn{4}{c|}{ номер білкової зони } \\
\cline { 2 - 9 } & 1 & 2 & усього & 1 & 2 & 3 & 4 & усього \\
\hline НК-35 & - & 0,70 & 1 & - & 0,09 & 0,15 & 0,21 & 3 \\
\hline K-99 & - & 0,70 & 1 & - & 0,09 & 0,15 & 0,21 & 3 \\
\hline P-01 & - & 0,70 & 1 & - & 0,09 & 0,15 & 0,21 & 3 \\
\hline В-99 & - & 0,70 & 1 & - & 0,09 & 0,15 & 0,21 & 3 \\
\hline ВК-2000 & 0,68 & - & 1 & 0,06 & 0,09 & 0,15 & 0,21 & 4 \\
\hline P-15 & - & 0,70 & 1 & - & 0,09 & 0,15 & 0,21 & 3 \\
\hline C-2000 & 0,68 & - & 1 & 0,06 & 0,09 & 0,15 & 0,21 & 4 \\
\hline 420 & - & 0,70 & 1 & - & 0,09 & 0,15 & 0,21 & 3 \\
\hline
\end{tabular}

2. Кількість білкових зон та ВЕР позаклітинних білків ізолятів P. оstreatus за вирощування на сусловому середовищі

\begin{tabular}{|c|c|c|c|c|c|c|c|c|c|c|c|c|c|}
\hline \multirow{2}{*}{$\begin{array}{c}\text { Штам, } \\
\text { ізоляти }\end{array}$} & \multicolumn{13}{|c|}{ Номер білкової зони } \\
\hline & 1 & 2 & 3 & 4 & 5 & 6 & 7 & 8 & 9 & 10 & 11 & 12 & $\Sigma$ \\
\hline HK-35 & - & - & - & - & 0,4 & - & 0,49 & - & 0,6 & 0,66 & - & - & 4 \\
\hline K-99 & - & 0,19 & - & - & 0,4 & - & 0,49 & - & 0,6 & 0,66 & - & - & 5 \\
\hline P-01 & - & 0,19 & - & - & 0,4 & - & 0,49 & - & 0,6 & 0,66 & - & - & 5 \\
\hline B-99 & - & 0,19 & 0,36 & - & 0,4 & - & 0,49 & 0,51 & 0,6 & 0,66 & 0,72 & 0,8 & 9 \\
\hline ВК-2000 & - & - & - & - & 0,4 & 0,47 & 0,49 & - & - & - & - & 0,8 & 4 \\
\hline P-15 & 0,15 & - & - & - & 0,4 & - & - & - & 0,6 & 0,66 & - & 0,8 & 5 \\
\hline C-2000 & - & 0,19 & - & 0,38 & - & - & - & - & 0,6 & 0,66 & 0,72 & - & 5 \\
\hline 420 & - & - & - & - & 0,4 & - & - & - & - & - & - & 0,8 & 2 \\
\hline
\end{tabular}

У ізоляту В-99 на ЕФС виявлено дев'ять білкових зон, з яких одна білкова зона мала малу $(0,19)$, шість - середню $(0,36,0,40,0,49,0,51,0,60,066)$ i дві $(0,72,0,81)$ - швидку рухливість в електричному полі. Подібність із контрольним штамом НК-35 спостерігалася за всіма чотирма білковими компонентами, які було виявлено у НК-35. Ізолят В-99 мав дві додаткові середньорухливі білкові зони 3 BEP - 0,36 і 0,51, які відсутні в інших досліджених ізолятів.

Білки ізоляту ВК-2000 складалися 3 чотирьох білкових зон: три - 3 середньою $(0,40,0,47,0,49)$ i одна - зі швидкою $(0,81)$ рухливістю. Ізолят ВК-2000 мав дві загальні 3 контрольним штамом НК-35 фракції білків із ВЕР - 0,40 і 0,49.

У ізоляту Р-15 виявлено один білковий компонент із малою $(0,15)$, три компоненти - із середньою $(0,40,0,60$ і 0,66$)$ і один - зі швидкою рухливістю $(0,81)$. Подібність із контрольним штамом НК-35 виявлено за всіма трьома білковими фракціями 3 середньою ВЕР.

Ізолят С-2000 мав на ЕФС ліофіляту КР одну білкову зону 3 малою $(0,19)$, три - із середньою $(0,38,0,60,0,66)$ і одну - зі швидкою $(0,72)$ рухливістю. Подібність із контрольним штамом НК-35 ви- являлася в ізоляту C-2000 за двома білковими зонами з ВЕР, що дорівнювала 0,60 і 0,66.

В ізоляту 420 виявлено тільки дві білкові фракції: $з$ середньою ВЕР, яка дорівнювала 0,40 , i швидкою ВЕР $(0,81)$. 3 контрольним штамом НК-35 цей штам мав подібний білковий компонент із ВЕР $-0,40$.

Таким чином, можна зазначити, що на сусловому середовищі, яке більш збалансоване за вмістом вуглеводів, гриб P. ostreatus здатен продукувати в КР ширший спектр білкових фракцій для їх споживання (від 2 до 9).

Висновок. За результатами досліджень встановлено певні загальні закономірності продукування позаклітинних білків для всіх ізолятів, які культивовано на рідкому живильному середовищі: здатність гриба продукувати білки 3 різною ВЕР $\epsilon$ відповідною реакцією на вуглецьвмісні речовини живильного середовища. Показано, що ізоляти, які мали найбільше значення показника накопичення біомаси на рідкому живильному середовищі та урожайності плодових тіл на лушпинні соняшника (B-99, К-99), характеризувалися появою додаткових білкових фракцій $(0,19-0,36-0,51-0,72-0,80)$ на електрофореграмах суслового живильного середо- 
вища порівняно 3 контрольним штамом НК-35. Методом електрофорезу доведено, що кількість білкових фракцій КР ліофілятів суслового середовища можна використовувати як додаткову оцінку підтвердження перспективності нових штамів гриба P.ostreatus до промислового культивування. Таким чином, за результатами

\section{БІБЛІОГРАФІЯ}

1. Дорошкевич Н. В. Визначення нових високопродуктивних ізолятів гриба Pleurotus ostreatus (Jacq.: Fr.) Kummer за допомогою коефіцієнта габітусу / Н. В. Дорошкевич, В. М. Шевкопляс // Вісник Полтавської державної аграрної академії. 2012. - № 1 (64). - С. 65-69.

2. Дорошкевич H. В. Господарсько-біологічна оцінка нових штамів гриба Pleurotus ostreatus (Jacq.: Fr.) Kummer: автореф. дис. ... канд. с.-г. наук. : спец. 06.01.06 «Овочівництво» / Н. В. Дорошкевич - К., 2010. - 20 с.

3. Дорошкевич Н. В. Оцінка нових ізолятів гриба Pleurotus ostreatus (Jacq.:Fr.) Kummer за допомогою інфрачервоної спектроскопії / Н. В. Дорошкевич, В. М. Шевкопляс // Вісник Полтавської державної аграрної академії. - 2012. - № 2 (65). C. 34-37.

4. Лавлинский Л. В. Введение в культуру дикорастущих видов вешенки (Pleurotus) как метод сохранения и рационального использования их природного биоразнообразия / Л.В.Лавлинский // Проблемы сохранения разнообразия растительного покрова Внутренней Азии. - Улан-Удэ, 2004. - Ч. 2. - С. 86-88.

5. Методы экспериментальной микологии / [И. А. Дудка, С. П. Вассер, И. А. Элланская]; под ред. В. И. Билай. - К. : Наукова думка, 1982. - 550 с. 6. Приседський Ю. Г. Статистична обробка результатів біологічних експериментів / Ю. Г. Приседський. Донецьк : Кассиопея, 1999. - 210 с.

7. Сафонов В. И. Исследование белков и ферментов растений методом электрофореза в ПААГ / В. И. Сафонов, М. П. Сафонова // Биохим. методы в физиологии растений. - М. : Наука, 1977. - С. 113-136.

8. Семенов С. М. Лабораторные среды для актиномицетов и грибов. Справочник / С. М. Семенов. - М. : ВО «Агропромиздат», 1990. - 240 с.

9. Трувеллер $K$. A. Многоцелевой прибор для вертикального электрофореза в параллельных пластинках полиакриламидного геля / К. А. Трувеллер, Г. Н. Нефедов // Биол. науки. - 1974. № 9. - С. 137-140.

10. Цизь О. М. Господарсько-біологічна оцінка штамів гливи звичайної [Електронний ресурс] / дослідження встановлено, що кількість білкових фракцій КР ліофілятів суслового середовища корелює 3 морфобіологічними показниками гриба. Тому електрофорез можна застосовувати в якості додаткового методу для попередньої оцінки нових ізолятів гриба P.ostreatus для промислового грибівництва.

О. М. Цизь, С. В. Лящук // Наукові доповіді НАУ 2007. - № 3 (8). - 7 с. - Режим доступу до журн.: http://www.nbuv.gov.ua/e-Journals/nd/2007-

3/07tomboe.pdf

11. Шнырева A. В. О критериях отбора дикорастущих штаммов вешенки для культивирования / А. В. Шнырева // Микол. и фитопатол. - 2002. Т. 36, вып. 4. - С. 55-62.

12. Babitskaya $V$. G. Biologically active substances of mycelia and fruting bodies of mushrooms Lentinus Fr. and Pleurotus (Fr.) P. Karst. / V. G. Babitskaya, T. A. Pushkova, V. V. Sherba, O. V. Osadchaya // Int. J. Med. Mushrooms. - 2001. - V. 3. - P. 106.

13. Lechner B. E. Search for new naturally occurring strains of Pleurotus to improve yields Pleurotus albidus as a novel proposed species for mushroom production / B. E. Lechner, E. Alberto // Rev. Iberoameric. Mycol. 2011. - V. 28, I. 4. - P. 148-154.

14. Matilla $P$. Contens of vitamins, mineral elements, and some phenolic compounds in cultivated mushrooms / P. Matilla, K. Konko, M. Eurola [and other] // J. agr. Food Chem. - 2001. - Vol. 49, № 5. - P. 2343-2348.

15. Ragunathan R. Nutritional status of Pleurotus spp. grown on various agro-wastes / R. Ragunathan, K. Swaminathan // Food Chemistry. - 2003. V. 80, Iss. 3. - P. 371-375.

16. Reddy G. V. Utilization of banana waste for the production of lignolytic and cellulolytic enzymes by solid substrate fermentation using two Pleurotus species ( $P$. ostreatus and $P$. sajor-caju) / G. V. Reddy, P. Ravindra Babu, P. Komaraiah, K.R.R.M. Roy and I.L. Kothari // Process Biochemistry. - 2003. - V. 38, Iss. 10. - P. 1457-1462.

17. Sánchez $C$. Detection of highly productive strains of Pleurotus ostreatus by their tolerance to 2-deoxy-D-glucose in starch-based media / C. Sánchez, G. Viniegra-Gonzaléz // Mycol. Res. - 1996. V. 100, I. 4. - P. 455-461.

18. Velazquez-Ceden M. A. Waste-reducing cultivation of Pleurotus ostreatus and Pleurotus pulmonarius on coffee pulp: changes in the production of some lignocellulolytic enzymes / M. A. Velazquez-Ceden, G. Mata, J.-M. Savoie // World Journal of Microbiol. \& Biotechnol. - 2002. - № 18. - P. 201-207. 